\title{
Women and Sustainable Development in Africa: Issues and Challenges from Nigeria
}

\author{
LekeOKE, PhD \\ Department of Political Science, \\ Faculty of the Social Sciences, \\ Ekiti state university, Ado- Ekiti, Nigeria. \\ E-mail: lekeoke@yahoo.com GSM: +2348033658474
}

\begin{abstract}
Globally, crave for sustainable development and increasing women participation in governance have been on unabated. This is premised on the belief that sustainable development is attainable where and when there is good governance and gender justice. Making use of library research and content analysis methodologies, the paper detailed in a systematic manner the missing link in sustainable development in Africa with particular emphasis on Nigeria. It analyses the current practice of 'sextortion' among the women in decision-making processes and leadership at the national, state and local levels and its impact on development. More so, the paper discusses the conditions that facilitate women's representation in decision-making processes within the context of the current socio-economic and political transformations. It also examines the linkages between women's presence in critical decision-making positions and sustainable development. The paper contends that most states in Africa are yet to attain development to be sustained. It blames the African leaders and the patriarchal states for the precarious pace at which the region develops. The paper concludes that sustainable development will remain a pie in the sky in Africa for as long as greed, self-centeredness and 'emperornic' disposition of African leaders as well as mass poverty and infrastructural decay continue.
\end{abstract}

Key words: Good governance, Development, Sustainable development, Gender justice.

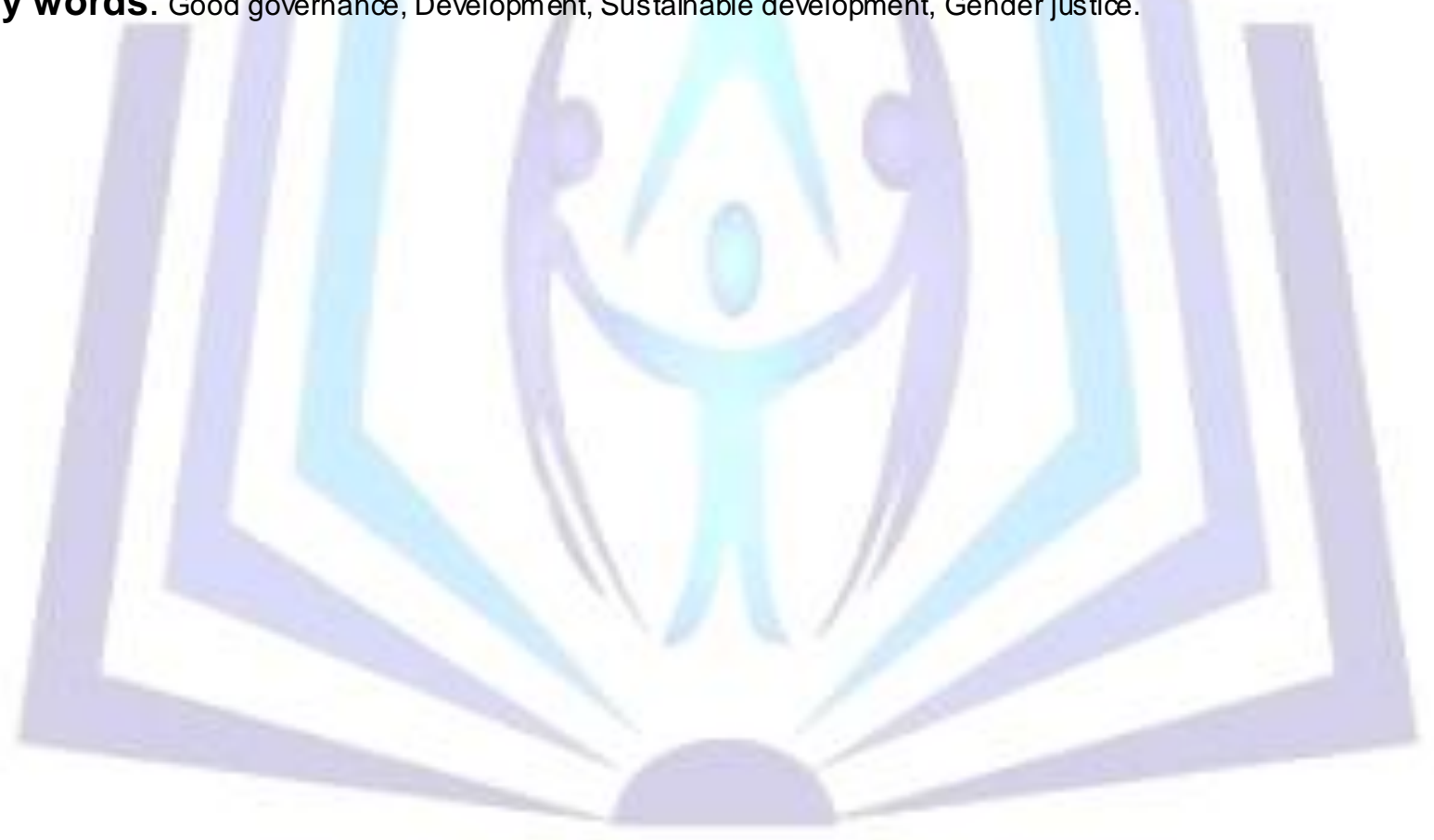

\section{Council for Innovative Research}

Peer Review Research Publishing System

\section{Journal: Journal of Social Sciences Research}

\author{
Vol. 9, No.1 \\ jssreditor.cir@gmail.com \\ www.jssronline.com
}




\section{Introduction}

As part of the democratization, globalization and development agenda going on across the world, the clamour has been for the empowement of women and their inclusion in societal administration on equal basis with their male counterparts. All over the world today, Africa inclusive, the quest by most stakeholders - governments, policy makers, women leaders, women organizations, non-governmental organizations (NGOs), etc. - has been for gender sensitive policies such that would guarantee equal representation of men and women in government and administration as well as societal issues generally. To this end, most countries have become signatories to many international agreements which are intended to boost the status of women and empower them in all spheres of life. This orchestration is premised on the need to develop human societies and the sustenance of such development as well as the general belief in the developmental potentials of women. However while it can be said that only very few countries in Africa have followed this pathway to development, a larger percentage of African countries are still hovering at a very snail pace and lagging behind in this democratized and jet age. Thus Nigeria is included in the list of countries still dilly-dally on the way forward for women. This has tremendously affected her crave for development as well as her political stability since it is established that men alone cannot herald the much desired development the country yearns for talk less of sustaining it.

Efforts have thus been on to ensure that development takes place globally. It was assured and expected that as societies develop, every living pers on will experience better living standards where necessities of live such as education, health and health care, employment as well as infra-structural provisions of water, light, roads and transportation, housing etc. would all improve in quantity and quality and be accessible by all and sundry as proofs of development. It is evident that past approaches to development have not equally benefited all members of the societies, though with claims that we are living in a postmodern era, yet economic and social problems are yet to get solution. This has led to new approaches to development tagged "Sustainable Human Development (SHD)". The Sustainable Human Development approach emphasizes the participation of all segments of the population claiming that the eradication of the imbalance between sexes with respect to education, economy, cultures to mention but a few are pre-condition for achieving long lasting and sustainable development (Gender Training Manual 1999).

Thus, rather than eradicating this gender bias and imbalance, the Nigeria state has not done much in this regard and has resulted to tokenism and politics of baiting to get the stage fully dominated by men. The resultant effect of this has been story of woes and underdevelopment occasioned by the predominantly male dominated politics. Nigeria has abundant resources, yet often suffers from high levels of political corruption, which distorts policy making and government resource allocation heightened insecurity occasioned by the menace of the dreaded Boko-Haram insurgency is daily unleashing terror on the country and the stigma of sit-tight syndrome that has infected most African states, among others, have made nonsense of her developmental efforts. This is to the effect that party politics has become a 'do or die' issue with the resultant effect that the citizens are further alienated from government and poverty blossoms amidst the nation's natural affluence. If people are the end of development, then their well-being is the supreme law of development. But the wellbeing of the people will only be the supreme law of development if they have some decision-making power. In most African countries Nigeria inclusive, women have been particularly relegated and discriminated against in governance and public administration. Their position of disadvantage has tended to leave their potentials unexplored and restrict the scope of labour, energy, and human resources available for (national) development. (Bassey - Ekpo\&Nkoyo-Toyo 2003; Friedlander 1995; and Williams 1978). In addition, for the success of the development process itself, the need to integrate women within the development framework has been stressed. One of the indexes of the progress and development of any nation is said to be the position of women in that society. Thus, women represent potent agents for positive change, depending on their condition and the opportunity offered them to actualize their potentials. Unlike the constitutions of some African countries notably South Africa and Uganda, the constitution of the Federal Republic of Nigeria takes no cognizance of the disadvantaged position of women and has no provision for gender equality and equity. Apart from the general reference to nondiscrimination on the basis of sex, there is nothing in the constitution that is aimed at redressing the disparities that exist along gender line in Nigeria. Even though Nigeria ratified CEDAW in 1985 and is a signatory to the Beijing Declaration and Platform for Action, the constitution does not recognize the enomous disparities along gender lines that prompted the United Nations to call for special actions for women's advancement. It does not provide any form of positive measure for accelerated redress of gender imbalances. By implication, therefore, women are hardly part of the decision-making processes and are excluded from policymaking and execution leading to their disempowement and marginalization. This official neglect has pauperized the country and robbed it of the potentials needed for development and sustainable development. It is against this backdrop that this paper attempts to fashion out a way of upturning this dooming fate of the country and make some useful suggestions towards sustainable development in Nigeria. To successfully do this, the paper is subdivided into five parts viz: the introduction, conceptual clarification, issues in women and sustainable development in Nigeria, challenges to sustainable development in Nigeria, towards sustainable development in Nigeria and conclusion.

\section{Conceptual clarifications}

\section{Development}

The word 'development' is a multi-phased concept. As a process, development affects all aspects of the life of the individual and the society, be it political, economic or social. Development is people centred; putting human face to human affairs is an important aspect of development. In line with Hobson (1965:289);

... a developed country is one in which the great mass of the inhabitants are able to procure, with moderate toil, what is necessary for living human lives, lives of frugal and assured comfort. 
Thus, indicators of such development would be seen in terms of the general material condition of the people, the level to which they have succeeded in reducing the exploitation of man-by-man, the level of popular participation in the socioeconomic set up and the level of individual freedom guaranteed in the society.

\section{Sustainable Development}

Sustainable Development means the ability of the present generation to meet their needs without compromising the ability of future generations to meet theirs (World Commission on Environment and Development, 1987:3), it means that $\mathrm{man} /$ woman is the focus of all developmental projects and as such he should be accorded a place in taking decisions that affect his/her life. Sustainable Development means the exploitation of natural resources for human survival without jeopardizing the ability of succeeding generations to satisfy their needs. It has to do with showing a greater consideration for future generations' means of livelihood even while trying to improve on our standard of living now. It is thus economic development with environmental protection (Ezekiel 2008:283). The Sociologist approach to sustainable development sees "people as instruments and beneficiaries, as well as victims of all development activities. To a greater extent, Seragldin (1993:10) described people's active involvement in the development process as the key to success." Cons equently, making development more participatory may be interpreted to mean "im proving the degree and quality of participation of previously disempowered groups and movements in development" (Jacob, 1994:10). Thus increasing women active participation in governance is pivotal to development. According to NCED (1987:49), the operational objectives of sustainable development are stated in the table below:

\section{Table 1: operational objectives of sustainable development}

\begin{tabular}{|l|l|}
\hline $\mathbf{S} / \mathbf{N}$ & Objectives \\
\hline 1. & Reviving growth \\
\hline 2. & Changing the quality of growth \\
\hline 3. & Meeting essential needs for jobs, energy, H20, and sanitation \\
\hline 4. & Ensuring a sustainable level of population \\
\hline 5. & Conserving and enhancing the resource base \\
\hline 6. & Re-orienting technology and managing risk \\
\hline 7. & Merging the environment and economics in decision making \\
\hline 8. & Re-orienting international economic relations \\
\hline 9. & Making development participatory \\
\hline
\end{tabular}

Source: World Commission on Environment and Development (WCED), the BrundHand Commission, (1987:9)

\section{Women}

The United Nations $(1986 ; 1995)$ defines women as the Feminine component of the human species who, apart from serving as a vehicle of nurturing human life, are also producers, consumers and an equally endowed agent for fostering a wholesome political, social, and economic development in the society. The participation of women in every aspect of national life is contributing to development. Women's involvement in power sharing and decision -making is a necessary, though not a sufficient condition for the sustenance of the nation's democratic experiment (Dauda, 2004:85).

Women constitute half of the world's population and have contributed significantly to the well-being of the human race (Enemuo, 1999:226). In Nigeria as elsewhere, it is said that women have always played five key roles - mother, producer, home manager, community organizer, and social, cultural, and political activist (UNDP, 1997:9). Despite their large number and crucial functions, the division of roles between the male and female sexes, as pres cribed by most cultures, assigns the subordinate position to women. Consequently, women have for long suffered various forms of discrimination, inequality, exclusion, and violence.

\section{Sextortion}

This refers to illicit sexual affairs, among other immoral acts, in the political circuit of using women as sex objects as a precondition for supporting them for public positions either in appointive or elective capacity. This practice is contributin $g$ to the political downfall of women as those who fail to surrender themselves to be sex objects in the hands of powerful men are often frustrated politically. The erstwhile senator of the republic representing Ogun West Senatorial District, Mrs. lyaboAnisulowo, under the ruling Peoples Democratic Party (PDP) in Nigeria attributed her failure to secure a returning ticket to the Senate to this social menace. According to senator Anisulowo (2007:10):

the top echelon of the PDP is peopled by lecherous men who

pestered her for sex in exchange for a return ticket to the senate....

I left the party (PDP) because of immoral acts and anti-progressive 
elements in the party, I can't give my body to any idiot, any filthy person

\section{Discrimination}

This refers to a situation of affording different treatments to different persons attributable wholly or mainly to their respective descriptions by race, tribe, place of origin or residence, sex or other local connection, political opinions, colo ur or creed whereby persons of one such description are subjected to disabilities or restrictions to which persons of another such description are not made subject or are accorded privileges or advantages which are not accorded to persons of another such description. According to the CEDAW document, the term "discrimination against women"means:

any distinction, exclusion or restriction made on the basis of sex which has the effect or purpose of impairing or nullifying the recognition, enjoyment or exercise by women, irrespective of their marital status, on a basis of equality of men and women, of human rights and fundamental freedoms in the political, economic, social, cultural, civil or any other field (WACOL 2008:19).

\section{Gender Equality}

This means equal opportunities for both sexes (male and female). That is opportunities and access to resources for the full realization of all possible potentials of the person, male or female. Gender equality issues need to be addressed from a human rights perspective. This requires removing all legal barriers to women's equality; ending violence against women and eliminating administrative, cultural, social, and economic obstacles to realization of women's rights and economic independence.

The term gender equality is defined in terms of equality under the law, equality of opportunity (including equality of rewards for work and equality in access to human capital and other productive resources that enable opportunity), and equality of voice (the ability to influence and contribute to the development process) (World Bank, 2001:69). Women's equal participation with men in power and decision-making is part of their fundamental rights to participate in political life and at the core of gender equality and women's empowerment (MDGs, 2000). Gender equality enhances gender justice.

\section{Governance}

Governance is defined by the World Bank as "the manner in which power is exercised in the management of a country's economic and social resources for development". Good governance, will in effect mean the use of power by the government i.e. the President, and his ministers, senators, members of House of Representatives and how the public service operates: (a) to promote democracy, accountability and transparency (b) to formulate and implement good policies (c) to effectively and efficiently manage the Nigerian human and financial resources in order to achieve sustainable national development, to achieve economic prosperity to alleviate poverty (Yahaya 1999:15).

Thus, achievement of the objectives of good governance is heavily dependent on the caliber and orientation of the political leaders in government and a competent, well trained, and motivated public service. From the World Bank definition, it is obvious that good governance can be guaranteed on a platform of a plural democratic system and a public service that can work and achieve results.

Good governance includes "both a broad reform strategy and a particular set of initiatives to strengthen the institutions of civil society with the objective of making government more accountable, more open and transparent and more democratic (Minogue, 1997:4)". It involves the traditions and institutions by which authority in a country is exercised. These include:

The process by which governments are selected, monitored and replaced;

The capacity of the government to effectively formulate and implement sound policies, and

The respect of citizens and the state for the institutions that govern economic and social interaction among them (kaufmann, kraay and zoido-Lobatan, 1999:1).

Good governance becomes very fundamental and imperative when viewed against the backdrop of massive deterioration of government institutions, pervasive poverty and widespread unemployment, corruption, as well as the near total collapse of moral and ethical standards engendered by nearly three decades of military rule in the country, which saw governance capacity weakened at all levels (World Bank, 2002; Ujomu, 2004). Former president Obasanjo vividly captures the country's deplorable national experience in the following words:

The parlous state of our infrastructure, huge debt and poverty combine with the moral decay in our society, the pervasive corruption, lawlessness, selfishness and cynicism that have taken over all areas of national life have led to a persistent deterioration in the quality of governance and the functioning of all public institutions. This has led in tum to the attitu de of indifference to the common good or welfare (Obasanjo, 1999a: 132; 1999b:140;2000a:160).

\section{Issues in women and sustainable development in Africa/Nigeria}

Africa is reputed to be in perpetual/persistent conflicts and violence (Bolle, 2000; Albert, 2002). For about 40 years now, the issue of war has been the major preoccupation of nations of Africa. From Liberia to Sierra Leone, Mali to Cote d'Ivoire, Somalia to Sudan, Rwanda to Burundi, African people are tom against one another in fratricidal wars that have grave consequences for regional peace and security in the continent (Adams 2013:155). It is thus doubtful whether development or its semblance can occur in a warring milieu talk less of its sustenance. The current political struggle in Mali has reached its crescendo, threatening the corporate existence and stability of the West African sub-region. Noting the magnitude of raging wars in Africa, Bolle's (2000:61) summits that: 
More than one African in five lives in a country that is fighting a war,

And nearly 20 countries have experienced civil war since 1960. The

Continuing conflicts that ravage African continent represent a heavy

social and economic burden. During a war, most of the country's resources

tend to be diverted away from development and towards supporting the conflict -

War is estimated to cost $\$ 1 \mathrm{bn}$ per year in Central Africa, without counting the cost

of aiding refugees, which is estimated to be about $\$ 500 \mathrm{~m}$ in the region.

Women can bring unique benefits to conflict zones. Research shows that women can play a key role in peace missions. According to UNIFEM's 2000 Independent Experts Assessment on Women, War and Peace, (Cited in Animashaun 2013:259) the presence of women in peace operations (including female police, interpreters, and specialists) makes a positive difference. According to the report, the presence of women:

(1) Improves access and support for local women;

(2) Facilitates communication with victims of assault, sexual abuse, violence, etc;

(3) Can provide a greater sense of security to local populations (women and children)

(4) Helps create a safer environment for women in which they are not afraid to talk;

(5) Makes peace keepers more reflective and responsible;

(6) Broadens the repertoire of skills and styles available within a mission;

(7) Can help to reduce conflict and confrontation.

The three pillars of sustainable development - economic, environment and social - are also relevant to discussions of gender equality. These dimensions have equal and interrelated importance as illustrated in some simple equations. Stressing the environmental and social dimensions of sustainable development in the absence of economics neglects the financial capital needed to pay for progress. Building up the economic and social pillars of sustainability while neglecting the environment degrades the natural capital needed for growth. Focusing on economics and the environment without attention to social factors can lead to green growth for a few. Given gender gaps worldwide, these few tend to be mostly men. Candice Stevens(2010)identified and expatiated on the above three pillars as follows:

\section{The Economics of Gender}

The economic crisis has led to heightened criticisms of the capitalist model, where growth is fueled by competition and the quest for profits. A lack of corporate responsibility among financial institutions - in the United States and banks worldwide - brought economic collapse and a recession that has touched almost all countries. It may not be a coincidence that this economic model has been built largely on the ambitions and perspectives of men. Why is it that women do not participate in the labor force to the same extent as men and, when they do, earn 18 percent less? About 60 percent of eligible women work in the richer nations and 40 percent in the poorer, but this work - whether formal or informal - is undervalued in all countries. And very few women reach the top ranks of business and management. This is variously ascribed to traditional attitudes, the glass ceiling or the old boys' network. It may be due more to an institutionalized form of gender discrimination embedded in the failure to adjust the male work model to fit the needs of women. Countries with government funded childcare and mandated family-oriented practices such as the Nordics (Denmark, Finland, Iceland, Norway and Sweden) and France have both more working women and higher birth rates than those without enlightened gender policies such as Japan and Korea. Although the female presence in the workplace is growing, women do not yet share in economic and political leadership. Because there are signs that gender trends may not change unassisted, more governments are proposing quantitative targets and quotas for corporations with regard to hiring and promoting women. Since 2003, Norway has required comorate boards to be at least 40 percent women and the country now leads the world in the number of female directors. Nonway also has quotas for the number of women managers in government at all levels. The French government has recently proposed that at least half of all company board members must be female within five years. The economic situation of women in developing countries is far worse, but the solution is not that different: let women manage the money. Seventy percent of the world's 1.3 billion people living on less than US\$ 1 a day are women or girls. United Nations and World Bank studies show that focusing on women in development assistance and poverty reduction strategies leads to faster economic growth than "gender neutral" approaches. Financial aid put in the hands of men tends to lead to a higher share wasted on personal use. Women are essential to poverty reduction because of their role in increasing economic opportunities for women is the cornerstone of development. Investing in women and girls - in their education, health and gainful activities — can have a multiplier effect on poor economies.

\section{Society and Gender}

Money is essential to both ecological and social progress. It is how that money is distributed and used that determines sustainability. The social pillar of sustainable development - and its emphasis on equity and equality - is the most politically-sensitive of the three dimensions and thus the hardest to address. It involves confronting negative social trends such as growing income disparities, rising unemployment, and a persistent gender gap. Unless they are addressed head- 
on, social concerns will continue to block progress on economic and ecological aims and the overall achievement of sustainable development. The direst trend of the current era is the widening gap between rich and poor both within and across countries. The 2008 Sustainable Society Index, which combines economic, environmental and social indicators to compare country performance, puts the United Kingdom at 50th and the United States at 66th place. Their low standing is due largely to rising poverty levels. While economic progress can improve the status of women, a country cannot advance if its women are left behind. As might be expected, the highest gender scores are in Iceland and Finland and the lowest in Chad and Yemen. But there are some unexpected findings. Several rich countries lag behind poorer countries when the gender markers are economic participation, education, health and political empowerment. For example, the United States trails at 31st place (out of 128 countries) behind South Africa (6) and the Philippines (9). Japan and Korea, champions of green growth, seriously lag in the gender stakes at places 75 and 115, respectively. Long-term sustainable development depends to a large degree on good governance practices that give equal weight to social factors.

\section{Environment and Gender}

It is far from proven that women are more environmentally conscientious than men as a rule. But women are more likely than men to be affected by environmental problems because of their social roles and more impoverished status in all countries. Coping with the effects of climate change and damage from extreme weather events such as stoms, floods, and cyclones tends to fall on women who hold together families and households. Women in developing countries who supply water and fuel for families find this increasingly difficult as environmental changes negatively affect resource supply and infrastructure. Increased costs for energy, health-care and food caused by the dis rupting effects of climate change disproportionately affect women, especially single mothers. Even in richer countries, women are vulnerable because of their lesser access to finance and reduced ability to adapt to climate change impacts. Because women are still rare in leadership positions, they have little power and influence to affect environmental policy. According to the InterParliamentary Union (IPU), about 18 percent of legislative seats worldwide are held by women and in many countries there are no female representatives at all. IPU studies also show that women in government give greater emphas is than men to social welfare and ecological issues. According to the UN, when women are well represented on governing bodies, the overall quality of governance tends to ise and levels of corruption sink. The equal participation of women and men in public life is one of the comerstones of the 1979 United Nations Convention on the Elimination of All Forms of Discrimination against Women (CEDAW).

In the particular case of Africa, the nations that make up the continent are fractured along ethnic, religious, linguistic and other lines. These fissures are aggravated by the inordinate desire of many of African's leaders to hang on to power, even when it is clear that they have outlived their use. The scarce resources which should be ploughed into development projects are spent on arms which are used to repress the citizenry. (The Nation, Friday, Jan.10, 2014:19. Editorials). This practice runs counter to development and further pauperized the continent.

In Nigeria, the fourth republic started on May 29, 1999 and as can be expected, the new spirit of democracy, return of civilian rule and advancement of women in many areas of life has led to an increase in the number of women in the political scene. However, it is still obvious that women have a long way to go in attaining equality alongside their male counterparts. Many news media reports and studies attest to the continued marginalization of women in politics especially in elective offices. In a public lecture by the Governor of Lagos state, BabatundeFashola, on the 29th of April 2009, a comprehensive statistical record on women political participation and representation was made available. This report showcases the joumey of women in politics since the retum of civilian and democratic rule.

The record as presented by the governor (April, 2009) shows that in 1999, there were only 12 women elected into the state assemblies against 978 men. In the senate, there were 3 female senators out of 109 senators selected that year. Also 13 women were selected into the House of Representatives. By 2003, after the elections, the number of female parliamentarians had increased slightly. The number of women elected into the House of Assembly of various states increased to 39 against 951 men while 21 women won seats into the House of Representatives against 339 men. Also four women won seats in the senate from a total of 109 senators, making 105 men. According to the statistical record, appointments into elective offices from 1999 shows that 833 persons were appointed with 86 of them women, indicating an average of about $11.9 \%$ women's participation and repres entation so far. Unfortunately, a concrete record for the 2007 election cannot be collated from the Independent Electoral Commission due to the fact that some elections results are still being contested till date before the various electoral tribunals in the various states.

\section{Challenges to Sustainable Development in Nigeria}

Doubtlessly, a number of factors have impeded the developmental aspiration of the Nigerian state and her quest for sustainable development in all areas of human endeavors. Most if not all of these problems are attributable to male dominance of the body polity. Some of these challenges are:

\section{Corruption}

Nigeria is one of the leading corrupt countries in the world. The Transparency International in her annual rating made Nigeria third, fourth and fifth most corrupt nation in the world in 2003, 2004 and 2005 respectively. Corruption has become part of governance in Nigeria. General Abacha was said to have stolen more than \$3 billion between 1993 and 1998 (Falola, 1999:2008). Cumulatively, Nigerian leaders, according to the Economic and Financial Crimes Commission, (EFCC), had within the last 40 years stole a total sum of $\$ 500$ billion (Amalu, 2006;1). Thus corruption has eaten deep into the fabric of the nation and has shaken it to its foundation. While the spate and ramified nature of corruption in Nigeria today cannot be holistically adduced to the military, it can be said to a great extent that the interplay of 'military-civilian- 
military' rule in the country has polluted both the military and the civilians and has diffused corruption to such an extent that the country has taken a frontal position in the comity of corrupt nations. The pervasive phenomenon of 'ten percent' kickbacks by public officers as executors of a whole array of public policies insisted on a prepayment to themselves of at least $10 \%$ (or more) of the value of the favour being sought by members of the public (contract, license, scholarship, employment, etc.) before performing the duty for which they are already being paid generous salaries and allowances from the public treasury are pointers to corruption. In the words of Kolawole (2005:13); the situation was so bad that the principle of public accountability and probity was observed more in disobedience than in obedience. In fact, corruption in Nigeria presently is best described as "grand". In his recent letter to the incumbent president, ex-president Obasanjo (2013:2) averred that:

\section{corruption in Nigeria has reached the level of impunity. It is also}

necessary to be mindful that corruption and injustice are fertile

breeding grounds for terrorism and political instability....Nigeria

is bleeding and the hemorrhage must stop.

Thus in Nigeria today, corruption grows at a geometric progression. Public officials now steal in billions and trillions with impunity. Unresolved aviation issues, pension fund scam, oil subsidy scam, non-remittances to federation accounts and a host of others remain controversial and unresolved matters of national debate. They have among others, been major sources of political divisions/crises and have been eroding confidence in national power. However, while chief Obasanjo's letter to the president is pontifical with regard to corruption in Nigeria, he (Obasanjo) himself cannot be absolved from corruption and corrupt practices in the country as he glossed over the menace of corruption. He used anti-corruption agencies like the Economic and financial crime Commission (EFCC) to witch-hunt perceived political enemies. Obasanjo did practically nothing to stem the social malaise while in office. This harboring of corruption and non-developmental posture of most African (Nigerian) leaders is having a deleterious effect on the yearnings and as piration for development. "Corruption, near absence of trans parency and utter dis regard for merit, quality and stand ards has featured as the cyclone that kick-starts destruction of African sub-national politics and threats to national power."(Atunwa, 2014:66). A nation that bleeds can hardly sustain any development. Sustainable development has thus remained a pie in the sky and wishful thinking in Nigeria.

\section{Security}

In the existing climate of economic challenges, mounting foreign debt servicing obligations, trans -border crimes, and environmental degradation, security issues in Nigeria can be aptly described in the reverse as "high politics". After over five decades of independence and 14 years of continuous democratic government, the Nigerian state has failed to perform the three basic responsibilities of a state, which are maintenance of peace, security, and the we lfare of its citizens. The improvement of the security situation in Nigeria, the enhancement of the ability of Nigeria to achieve her national security objectives and combating terrorism remain the main challenges (Pogoson 2013:51\}. National security in Nigeria ," as in most of Africa, is not threatened by conventional threats of armed attack by other countries" but by more menacing measures "many of which flow from the very weakness of the state and its absence of control over its own territory". Like a number of states in Africa, Nigeria presents the "shell" of the teritorial state where national security is equated with that of the governing elite- "governing" in the interests of their own preservation and advancement with limited provision of human security for their citizenry" ( Pogoson 2013:21\}. Such states are variously described as weak quasi-states, intemediate states or predatory states (Workshop on Human Security in West Africa, 2001:10). Thus from political to wishful killings, killings from accidental discharges from security agents, carnages on our high ways, kidnapping and ransom payment, security in Nigeria today is very precarious culminating in lawlessness, chaos and underdevelopment. Since no development can occur in a state of lawlessness, the Nigeria state has remained perpetually underdeveloped with little or nothing to sustain development.

\section{Terrorism}

Though devoid of one universally acceptable definition, due to its changing character, terrorism destroys. The UN Security Council Resolution 1566 (2004) defines terrorism as: "criminal acts including against civilians, committed with the intent to cause death or serious bodily injury, or taking of hostages, with the purpose to provoke a state of terror in the general public or in a group of persons or particular persons, intimidate a population or compel a government or an international organization to do or to abstain from doing any act". Although there is no consensus amongst UN memberstates as to the precise definition of terrorism, the A.U. convention defines terrorism as:

any act by an individual, group, organization, a state or its agents (excluding

liberation struggles, armed struggles against oppressive governments, colonization,

occupation, aggression and domination by foreign forces), which is a violation of

the criminal laws of a state party and international law instruments criminalizing it,

and which may endanger the life, physical integrity or freedom of, or cause serious

injury or death to any person, any number or group of persons or causes or may

cause damage to public or private property, natural resources, environmental or 
cultural heritage and is calculated or intended to achieve those objectives in Article

1(3) (a) (i-iii). (A.U. Convention on the Prevention and Combating of Terrorism; 1999)

The menace of Boko-Haram has caused wanton destruction in material and human resources to Nigeria and Nigerians in recent time. This has really rubbished governmental intentions at development in the terrorist prone zone in the Northern part of the country.

\section{Poverty}

There is no doubt that poverty is one of the root causes of the women problem especially in Africa and the third world. Certainly, a society that had for long neglected the proper education and economic empowement of women had wittingly or unwittingly ensured that her women fold is kept in the dark economically and otherwise. Broom and Selznick (1973:174) observed thus:

The economic status of women is a special case because their pres tige and authority are... seen as a byproduct of the achievement of their husbands, because their position in the labour force is ambiguous and intermittent.

In other words, men control, dominate, and distribute the earth's resources according to their fancies. While women make up about 50 percent of the world's population, they earn only one tenth of the world's income and own less than one percent of property (MDGs, 2004/5: 2-5). One percent of the world's property is registered in their names. Osarenren (1993:90) observes that in Sub-Saharan Africa, only 47 percent of women aged 15 and above are economically active compared to the 85 percent among the men folk. Therefore, in the light of poor financial strength, women are really relegated to associate positions.

The relationship between poverty and gender inequality can differ significantly across countries as well as across dimensions of inequality, and higher incomes do not always imply greater equality in every dimension. In some contexts, specific forms of gender disparity confer status on the family. In some societies, for example, the higher a family's socioeconomic status, the greater the investment in female modesty and seclusion - symbols of that status (Chen, 1995). Nonetheless, there is a strong association between poverty and gender disparities in basic education and health that are critical to girls' and boys' ability to participate in development and to attain a basic quality of life (Ibid: 63). This realization must have informed the commitment of the global community to eradicating poverty through the Millennium Development Goals (MDGs). In the particular case of Nigeria, the most immediate source of the disconnect between Nigeria's wealth and its poverty is a failure of governance at the federal, state and local levels. Lack of transparency and accountability has eroded the legitimacy of government and contributed to the rise of groups that embrace violence and reject the authority of the state (the Nation 26/8/2009:14).

\section{Energy crisis/shortage}

Presently, the power situation in Nigeria is horrible and highly unproductive with most businesses stifled and liquidated. Since energy is pivotal to development, shortage of energy or its epileptic supply has made a mess of the developmental aspirations of the Nigerian state. Thus in spite of the huge sum expended on power generation, the country is still fathoming ways of generating 4,000 megawatts when a country like South Africa for example is improving on its 40,000 megawatts.

Other challenges to sustainable development in Nigeria revolve round leadership, self-centeredness, deceit, policy abandonment etc.

\section{Conclusion}

Empirical evidenceattests to it that the bane of development in most African states and especially in Nigeria has been male domination. From independence till now (2014) women have remained marginally in the public service occupying about $11 \%$ in spite of the fact that they constitute about $50 \%$ of the total population. The inhibiting culture of patriarchy as well as the undemocratic nature of the country's democracy culminating in economic comatose has obliterated the chance of the country in heralding development. In practically all fronts; educational, economic, energy, security, transport, social, environment etc., the country has performed poorly. This poor performance has tilted the state towards the categorization of a failed state. The state policies have become 'theirs' rather than ours. Governance is synonymous with deceit with leaders competing corruptly and attempt to outsmart one another on treasury looting. This situation signals nothing but underdevelopment and retrogression.

\section{References}

1. Albert, I.O., (2002): "The impact of blood diamond on Protractedness of African

2. Conflicts", in Ojielo, O., ed. Rethinking Peace and Security in Africa. Lagos.

3. CPABooks.

4. Amalu, C. (2006): "Over N60 trillion was stolen by Nigerian past leaders - EFCC Vanguard, Lagos. Vanguard Newspapers Ltd. October 17.

5. Anisulowo, I. (2007): "I lost PDP ticket over sex" Sunday Sun March 7

6. Animashaun, R. O (2013).“Women in peacekeeping and Peacebuilding” in Albert, I. O. 
7. andEselebor, W. A. (Eds.) (2013): Managing Security in a Globalized World.

8. Ibadan. John Archers Ltd.

9. Atunwa, R. (2014) "Corruption bane of government programmes" in the Nation,

i. Thursday, Jan 9.

10. Adams, A. (2013): "Rethinking African Union's Mediation Role in Africa” in Albert, I.

i. O. and Eselebor, W. A. (Eds.) (2013): Managing Security in a Globalized

11. World.lbadan. John Archers Ltd.

12. Bolle, J. (2000): 'Africa: Lost Continent or Tomorrows Success Story?' Humanitarian

i. Affairs Reviews, Autumn.

13. Bassey, E. B \&Nkoyo, T. Eds. 2003.Nigerian Women \& Political Entrism. Lagos:

14. Gender and Development Action (GAD A).

15. Boserup, E. 1970.Women's Role in Economic Development. New York: St. Martins Press. Pg. 20

16. Chen 1995. Cited in World Bank. 2001: Engendering Development through Gender

17. Equality in Rights, Resources, and Voice. A co publication of the World Bank

18. and Oxford University Press.

19. Enemuo, F. C. 1999. Gender and Women Empowement. Eds. Anifowose, R. and

20. Enemuo, F.C. Elements of Politics.Lagos: Malthouse Press Ltd.

21. Falola T. (1999): The History of Nigeria. London. Greenwood Press.

22. Friedlander, E. 1995. Look at the World through Women's Eyes. Plenary Speeches from

23. the NGOs Forum, Beijing: 777: United Nations Plaza.

24. Hobson, J. A. 1965. Imperialism. An Arbor: University of Michigan Press.

25. Jacob, M. (1994): Towards a methodologist Critique of Sustainable Development. The

i. Journal of Developing Areas, Vol.28 no 2, January

26. Kolawole D. (2005): The symmetry of an Asymmetric Relationship; Nigerian Foreign Policy and military rule $14^{\text {th }}$ Inaugural lecture, University of Ado Ekiti, Nigeria, Ado-Ekiti. The University of Ado-Ekiti Press.

27. Minogue, M. (1997): "The Principles and Practice of Good governance" Law and Governance 4, British Council Briefing.

28. Obasanjo, O. (1999a): "Inaugural Speech of 29 May, 1999" in RECALL NO. 1 (January 2000).

29. Obasanjo, O. (1999b): "On the Moral Foundations of Nigerian Policy", Independence Day Address of $1^{\text {st }}$ October, 1999," in RECALL NO. 1 (January 2000).

30. Obasanjo O. (2000) "New Year Speech at the May Day Parade of $1^{\text {st }}$ May 2000" in RECALL NO. 2 (January 2000).

31. Obasanjo, O. (2013): “Obasanjo bombs Jonathan” The Punch, Thursday, December 12. Lagos. Punch (Nig.) Limited.

32. Oruche, J. 2004. Women and National Development. The Comet April 27. Pg. 16

33. Pogoson, A. I. (2013): "Nigeria's national security in an age of terrorism". Maiden Departmental Lecture.Department of Political Science, Faculty of the Social Sciences, University of Ibadan, Nigeria. Ibadan. Gold Press Limited.

34. Serageldin, (1993): "Making Development Sustainable, Finance and Development.

i. December

35. Stevens, C. (2010): Sustainable Development Knowledge Partnership. The Fredericks Pardee Center for the study of the Longer-Range Future.Sustainable Development Insights.Boston University. April.

36. World Bank (2002): "Memorandum of the president of the Intemational Development Association and the Executive Director on an Inter-Strategy update for the Federal Republic of Nigeria: Report No. 2363.

37. World Commission on Environment and Development (WCED) (1987): Our Common Future. Oxford University Press

38. WACOL (2001).Women's Socio-Economic and Legal Rights. Enugu. Women's Aid

a. Collective

39. United Nations Development Programme (1995) Human Development Report. New York. Oxford University Press. 


\section{ISSN 2321-1091}

40. Ujomu, P. O. (2004): "Development Institutions Participation and the Problems of Social Engineering in an African Nation-State" in Ajayi, K. and Ayodele, B. (eds.): Prespectives on Democracy and Development in postmilitary Nigeria. Ibadan, Julius and Julius Associates.

41. Yahaya, A. D. (1999): "Public Service and good governance", in the Guardian, Friday, June 4.

42. The Nation 26/8/2009:14 is Nigeria a failed state? Editorial. Lagos. Vintage Press Limited,

43. The Nation, Friday, Jan.10, 2014:19. Editorial. Lagos. Vintage Press Limited, 